\title{
Pick the Idea, Organize, Write It Up (POW) \&Topic, Reason, Explain, Ending (TREE) for Teaching Cohesive Devices in EFL Students
}

\author{
Yunda Darajatul Ilmi \\ Sebelas Maret University
}

\begin{abstract}
The aim of this research isto explore how the way I use POW+TREE strategy to improve students' cohesive devices mastery. This research was conducted in one of junior high school in Surakarta at eighth grade students. Based on the preliminary study, I found that students had writing problems in mastering cohesive devices. I chose POW+TREE strategy to improve their writing problems in mastering cohesive devices. This study used Classroom Action Research (CAR) research design. The CAR activity involves of planning, acting, observing, and reflecting. The subjects of this study are 29 students in the eighth grade in academic year 2016/2017. The data were collected through writing test, observation, and field-notes.

There was an improvement in the students' score from preliminary study and after the implementation of the strategy. The average score after implementation in cycle 2 was 83.24. As the result of observation sheet, it showed that the students' interest also increased that was proved by students' activeness in asking difficult words. The field notes showed that in the teaching and learning process, most of the students enjoyed in writing activity. Hence, it can be concluded that the implementation of POW+TREE strategy was successful for students' writing ability in mastering cohesive devices.

Considering that the strategy had successfully improved the students' writing ability in mastering cohesive devices it is suggested for future researchers to conduct an experimental research related to this strategy for the same skill.
\end{abstract}

Keywords: writing, cohesive devices, POW+TREE strategy, CAR

\section{INTRODUCTION}

Writing is a basic skill which must be possessed by the students.This skill is needed in every teaching and learning process in English lesson. It is not only to express their imagination in the written language but also to develop students' creativity and motivation in writing.In writing activity, the writer must know how to communicate their ideas in order to make the readers understand what the writer haswritten (Rosmeri, 2014: 1). According to Graham \& Perin (2007: 23), writing plays main roles in the school. "First, it is a skill that draws on sub-skills and processes. Second, writing is a means to extend and deepen students' knowledge" (Graham \&Perin, 2007: 23). It means that the students have to master their writing by learning the writing process itself. By learning the writing process, students will understand deeply how to write a good writing product and increase their knowledge creativity.

Based on the interview with the English teacher and three students in the preliminary study that conducted at September $26^{\text {th }} 2016$, I found that students have difficulties in writing for a variety of reasons. First, the teacher did not use the certain technique in teaching and learning process. He always used the threephase technique, the traditional technique, to teach his students. He did not use the effective strategies to deliver the materials. The second problem is most of the students did not finish their homework and only copy and paste their friends' homework before the lesson began.

Then, the third problem is most of the students were confused to follow the teacher's strategy because sometimes the teacher has to leave the teaching and learning process for some meetings. Then he gave the students task to do in his lesson. So the students were confused to do and finish the task and afraid to ask how to do the task. The English scores were combined into only one score of English lesson. That was the last problem. It was not divided into certain score such as listening score, speaking score, reading score, and writing score. So, the students did not know how far they learned the lesson and how their progress in learning the English materials.

To evaluate my research, I used 3 frameworks from Halliday and Hasan' theory (1976) about cohesive devices, Brown's theory (2003) about the writing scoring rubric, and Kubina, Mason, Vostal, \&Taft 
(2011) about the steps in implementing POW+TREE strategy. There are five general components that must be carefully considered in writing. They are organization, content, grammar, mechanics, and vocabulary (Brown, 2003: 244 - 245). From those five general components in writing, there were many students have difficulties in it. Based on the interview with the English teacher on September $26^{\text {th }} 2016$, he said that developing the ideas and grammar were the most problem in students' writing. Besides, they had difficulty in making their sentences coherent. Students' difficulty might happen because of the lack of ability in using cohesive devices. They do not use cohesive devices correctly so that to reduce the mistakes while using them, students are not using them in their writing. Furthermore, they tend to make simple sentences and ignore the cohesion and coherence in their writing. They just jumped from one sentence to another sentence. In order to make students able in linking their writing smoothly, the use of cohesive devices is needed.

Based on the preliminary study on September $26^{\text {th }} 2016$ by giving the writing test, the mean score of the students was 48.77. Most of the students have difficulty in all of the indicators. Their content, organization, grammar, mechanic, and vocabulary were low. They also did not know how to write the text cohesively and coherently. Many students wrote the text based on what they thought without considering the writing components.

To solve those difficulties, I have strong desirability to improve students' writing skill especially in mastering cohesive devices by using POW + TREE strategy. There are many experts that had been conducted research about POW+TREE strategy in writing. They are Mason, Kubina, and Taft (2009); Lane, Harris, Graham, Weisenbach, Brindle \&Morphy (2006); Fahim\&Rajabi (2015); Baghbadorani\&Roohani (2014).

All of their studies showed that the students have difficulties in writing. According to the above studies, SRSD instruction model with a focus on POW+TREE can be effective at improving students' writing in a story and persuasive writing. The literature of those areas tends to focus on elementary, preintermediate, and undergraduate students. Thus, there was a gap to implement the POW+TREE strategy on the writing recount text for junior EFL learners. All of those studies used SRSD instruction model with POW and TREE while in this study just focus on implementing POW and TREE without using SRSD instruction model. However, all studies above used experimental research design while this study used action research to enhance the students' writing with a focus on cohesive devices mastery. Hence, by using POW+TREE, it solved the students' difficulties in personal references and temporal conjunction mastery.

\section{RESEARCH METHOD}

The research design of the study was Classroom Action Research (CAR). Tomal (2010: 10) defined action research as "a systematic process of solving educational problems and making improvements". An action researcher utilizes an appropriate intervention to collect and analyze data and to implement actions to address educational issues. By implementing the actions, it is expected to solving the educational problems during teaching and learning process. In line with Tomal (2010), McNiff\& Whitehead (2006: 7) stated that action research is "a form of enquiry that enables practitioners everywhere to investigate and evaluate their work".

Kemmis, McTaggart, \& Nixon (2014: 11) explained that CAR is an educational research that "involves the use of qualitative, interpretive modes of enquiry and data collection by teachers (often with help from academic partners) with a view to teachers making judgments about how to improve their own practices". In CAR, English teachers improve the quality of their instructional performance by developing innovative instructional strategies to solve their classroom problems.

Based on all of the theories above, it can be concluded that CAR is an educational research that involves gathering, interpreting, and analyzing data from teaching and learning process to improve the quality of instructional performance and solve the problem in the classroom activities.

English teachers conduct CAR because their class has problems. Furthermore, they improve the quality of their instructional performance by developing innovative instructional strategies to solve their classroom problems. Based on the preliminary study, I have strong desirability to improve students' writing skill especially in mastering cohesive devices by using POW+TREE strategy.

CAR activity involves repeated cycles. Based on Kemmis\&McTaggart (1988, cited in Burns, 2010: 7), the CAR cycle involves four broad phases in a cycle of research. They are Planning, Action, Observation, and Reflection. McNiff\& Whitehead (2006: 9) proposed the CAR cycle as action-reflection. The processes are observe, reflect, act, evaluate, modify, and move in new directions. They said that CAR aims to be a disciplined and systematic process.

To sum up, CAR activity involves repeated cycles, each consisting of planning, acting, observing, and reflecting. According to Kemmis\&McTaggart(1988, cited in Latief, 2012: 145), the result of one cycle is used to determine the need for the following cycle, until the problems are solved by the strategy. Hence, in this study, I implemented the POW+TREE strategy in two cycles. Then, to evaluate the study, I used some instruments. They are writing test, observation sheet, field notes, and interviews. In analyzing the data, Burns 
(2010: 104 - 105) proposed five steps in CAR. They are assembling, coding, comparing, building meanings and interpretations, and reporting the outcomes.

\section{RESULTS AND ANALYSIS}

By analyzing the data obtained, I found the answer regarding my research problem in improving the students' ability in mastering cohesive devices. By implementing the strategy, students could improve their writing in mastering cohesive devices. The steps of POW+TREE strategy give a chance for the students to practice their writing ability. POW+TREE strategy was developed to improve the students' skill in writing. It was proven by Baghbadorani\&Roohani's (2014) study. They found that the students who receive SRSD model for POW and TREE have greater gains in essay quality when compared to students who receive traditional writing instruction. In line with Baghbadorani\&Roohani (2014), Lane, Harris, Graham, Weisenbach, Brindle \&Morphy (2006) also conducted the study in the same topic. Their result of their study showed that there were some improvements in story completeness, length, and quality of writing. Santangelo, Harris, \& Graham (2007, p. 13) pointed out that "the three steps of TREE strategy is designed to help students identify what they want to accomplish, generate an outline that includes all the basic parts of an essay". They added that the TREE steps can help the students to remember how they write outline ideas based on some essay elements such as topic sentence, reasons, and ending.

In addition, the students' interest was also increased that was proven by there were many students asked questions related to the materials and some difficult words. Besides, the field notes showed that in the teaching and learning process, most of the students took notes and had a curiosity about the materials. Overall, the improvement of students' writing ability in mastering cohesive devices by using POW+TREE strategy was successful for eighth grade in the VIII- A class in the one of junior high school in Surakarta.

To sum up, their mean score improved greatly from preliminary test to final test in cycle 2 . It means that their ability in writing also improved better than before. Overall, the improvement of students' writing ability in mastering cohesive devices by using POW+TREE strategy was successful for eighth grade in the VIII - A class in the one of junior high school in Surakarta.

\section{CONCLUSION}

The main purpose of this research is to enhance the students' writing ability in mastering cohesive devices by using POW+TREE strategy. Hence, the result shows that POW+TREE has worked well in solving the problems. There are some suggestions for English teachers and future researchers.

a. English teachers

Regarding teaching writing ability, this research has proved that the using of POW+TREE strategy could improve students' writing ability in mastering cohesive devices. The teachers are suggested to use this strategy to improve their students' cohesive devices mastery.

b. Future researchers

Considering that POW+TREE strategy had successfully improved the students' cohesive devices mastery in eighth grade in one of junior high school in Surakarta, the future researchers are suggested to conduct an experimental research related to this strategy in the same skill.

\section{REFERENCES}

Baghbadorani, E. A. \&Roohani, A. (2014).The Impact of Strategy-Based Instruction on L2 Learners' Persuasive Writing.Procedia - Social and Behavioral Sciences 98 (2014) 235-241.

Brown, H. D. (2003). Language Assessment: Principles and Classroom Practices. San Fransisco: Longman.

Burns, A. (2010). Doing Action Research in English Language Teaching. New York: Routledge.

Fahim, M. \&Rajabi , S. (2015). Applying Self-Regulated Strategy Development Model of Instruction to Teach Writing Skill: Effects on Writing Performance and Writing Motivation of EFL Learners.International Journal of Research Studies in Education. Volume 4 Number 2, 29-42. DOI: 10.5861/ijrse.2015.1009.

Graham, S. \&Perin, D. (2007).Writing next: Effective strategies to improve writing of adolescents in middle and high schools - A report to Carnegie Corporation of New York. Washington, DC: Alliance for Excellent Education. 
Halliday, M. A. K. \&Hasan, R. (1976).Cohesion in English. Hong Kong: Longman Group.

Kemmis, S. McTaggart, R. \& Nixon, R. (2014).The Action Research Planner: Doing Critical Participatory Action Research. Singapore: Springer.

Kubina, R. M. Mason, L. H. Vostal, B. R. Taft, R. J. (2011). Self-Regulated Strategy Development Instruction: Effects of Lesson Structure on Teacher's Behaviors.A Multidisciplinary Journal.Volume 17 Number 3.

Lane, K. L. Harris, K. R. Graham, S. Weisenbach, J. L. Brindle, M. \&Morphy, P. (2006). The Effects of Self-Regulated Strategy Development on the Writing Performance of Second-Grade Students with Behavioral and Writing Difficulties.The Journal of Special Education (2008) 41: 234.

Latief, M. A. (2012). Research Method On Language Learning An Introduction. Malang: UM Press.

Mason, L. Kubina, R. M. \& Taft, R. J. (2009).Developing Quick Writing Skills of Middle School Students with Disabilities.The Journal of Special Education 44(4).

McNiff, J. \& Whitehead, J. (2006).All You Need to Know about Action Research. Great Britain: The Cromwell Press. 